\title{
Bottlefield where Doctors and Paramedics are on Frontline
}

\author{
Dr Dashrath Kafle
}

Chief Editor

\section{Dear Colleagues,}

We probably had never imagined that a tiny virus can shake the whole world. We had never even thought that we have to be locked inside our house not for hours, neither days but for weeks!!! Yes this is the grave reality everywhere in the world. Rich or poor, young or old, boys or girls, leaders to lay people nobody is spared from Corona outbreak. As WHO has already declared pandemic for this outbreak, neither you nor me have any means to know how our future will be amidst this stressful situation. We heard about it but our generation of human being had never witnessed such a widespread Pandemia. The worst hit countries are still struggling to recover and many countries are yet to withstand the cruel test of nature. Let's hope we will overcome this situation soon and get back to our regular life. But what next!!!!

The world economy had never seen such a worst downfall in last 100 years. Is this going to affect us? Is this going to affect our practice? Or is this going to affect the way we practice? Hundreds of clinics have been shut down. Truthfully, on those hundreds of clinics, the bread and butter of thousands of families are associated. In developing countries like Nepal, many people live on a day to day or monthly wages. If the whole country is locked down for weeks, their ray of hope starts to fade away and deep uncertainty prevails. In this adverse situation, being form the very prestigious profession in the world, we have the moral responsibility to our society and moral liability to those families who are associated with us via our staffs. On the other hand we have ethical responsibility to our students and hundreds if not thousands of patients who have put outmost trust upon us. So we should just not sit back at home and do nothing. This is the time where our inner heroism should come forward for the sake of humanity. We should be lending our helping shoulder to our colleagues, countrymen, society, staffs and of course our students and patients. As being on the health care profession, if the spread of virus is severe and frontline healthcare professionals are in short, we should come forward to help our colleagues and government. Yes of course personal safety must be secured. Few days back while I was driving to my work, I felt that country is in a serious war. There is nobody in the street except ambulances and policemen. Cities full of life have suddenly been deserted. I realized that we are fighting a war without enemy. We are fighting a huge battle against a Virus which has spared no one irrespective of their status, country and ideology. We are fighting a battle in which doctors and paramedics are the real warriors. If we had envisioned that we will be fighting war against pandemic, probably our leaders would have allocated more budget on health and education than on weapons and militaries. We as a healthcare provider would have more preparedness for the disease and disaster. This is the time to think and rethink how we should be prepared in future. Preparedness should be in our culture. This pandemic has already given the lesion that countries with good biological disaster preparedness have less damage than other countries.

This is the time to implement distance learning and e-learning activities for ourselves and students. This is the time to address e-counselling and consultations to our patients. This is the time to show solidarity to our staffs and say "do not worry, I will help you and your family". This is the time to help people in need because many of us are in a position to give. This is the opportunity to give back to the community which owe a lot from us without any expectation. Let us all stay safe and extend our help to those in need. If there are lives left, then only we have people to treat. Let us all work together to save the life of countrymen, let us all work together to save the human race!!! 